\title{
Determination of Optimal Condition to Obtain the Bromelain from Pineapple Plants Produced by Micropropagation
}

\author{
Nadjma Souza Leite ${ }^{1}$, Aloísio André Bomfim de Lima ${ }^{1}$, José Carlos Curvelo Santana ${ }^{2}$, \\ Francisco Luiz Gumes Lopes ${ }^{3}$, Ana da Silva Lédo ${ }^{4}$, Elias Basile Tambourgi ${ }^{5}$ and Roberto \\ Rodrigues de Souza ${ }^{1 *}$ \\ ${ }^{I}$ Departamento de Engenharia Química; Universidade Federal de Sergipe; Av. Marechal Rondom, S/N; 49100-000; \\ Aracaju - SE - Brasil. ${ }^{2}$ Departamento de Ciência Exatas; Universidade Nove de Julho; 01504-001; São Paulo - SP - \\ Brasil. ${ }^{3}$ Departamento de Química; Instituto Federal de Sergipe; Aracaju - SE - Brasil. ${ }^{4}$ EMBRAPA Tabuleiros \\ Costeiros; Av. Beira Mar 3250; Aracaju - SE - Brasil. ${ }^{5}$ Departamento de Engenharia de Sistemas Químicos; \\ Faculdade de Engenharia Química; Universidade Estadual de Campinas; 13083-852; Campinas - SP - Brasil
}

\begin{abstract}
This study aimed to obtain the condition of maximum bromalein activity in different parts of pineapple plants produced in vitro, by micropropagation. The sStems and leaves of Pérola and Imperial cultivar plants were evaluated after three and eight months of in vitro cultivation in Murashige and Skoog medium without growth phytoregulator, macerated in potassium phosphate buffer at different pH values (5.7, 6.7 and 7.7). Total protein and proteolytic activity were determined in the samples after three-and eight-month cultivation periods. For both the cultivars, the best results were obtained at pH 5.7 in extraction media. Pérola cultivar, showed higher bromelain activity in the leaves cultivated in vitro for three months $(0.0194 U / \mathrm{mL})$ while in the Imperial cultivar, it was higher in the stem after eight months $(0.0179 \mathrm{U} / \mathrm{mL})$. Imperial cultivar showed higher bromelain activity than the Pérola's.
\end{abstract}

Key words: Enzymatic activity, bromelain, Pérola pineapple, Imperial pineapple, production in vitro

\section{INTRODUCTION}

Bromelain is a protease of vegetal origin obtained from several species of the Bromeliaceae family. Ananas comosus L Merril is the main source of bromelain, a product of great commercial value that is found in its fruits, stem, leaves and roots. It is used in food and pharmaceutical industries. Its efficacy has been reported to heal several health problems such as angina, indigestion and respiratory problems (Ferreira et al. 2011; Hale et al. 2005). Commercially bromelain is obtained from the pineapple stem. The fruit is also a good option for its source as it has higher proteolytic activity than in the stem. A good quantity of fruit residue is generated by the pine apple processing factories, which can be used as raw material (Ferreira et al. 2011; Fileti et al. 2009 and 2010; Lopes et al. 2012; Parks 2001).

In vitro cultivation is an important procedure in the multiplication of different species, This technique can be applied on the industrial scale. The micropropagation, besides offering a greater amount of seedlings in a short period of time, enables total control of environmental conditions during the propagation and preservation of matrix

*Author for correspondence: rrsouza@ufs.br 
plants without risk of infection (Pasqual et al. 1998, 2001; Moreira et. al. 2003; Barboza et al. 2006). This technique can be an option for large scale production of vegetal material from pineapple plant aiming to commercially exploit the bromelain enzyme.

Considering the increasing development of biotechnology, it has become necessary to develop new techniques to separate and purify biomolecules, such as enzymes and proteins of animal, vegetal and microbial origin. These techniques should maintain the chemical and physical properties of molecules and, further, should be highly efficient in the purification. Thus, the study on both purification and alternative extraction methods is of great interest, aiming to obtain more economically feasible processes. Hence, solid-liquid extraction applied to a technological process is extremely important for the development of new protein extraction and purification methods (Ferreira et al. 2011; Fileti et al. 2009 and 2010; Lopes et al. 2009; Silveira et al. 2009). This study aimed to quantify bromelain activity in different parts of pineapple plants produced in vitro.

\section{MATERIALS AND METHODS}

\section{Micropropagation}

Pérola and Imperial cultivars were provided by the EMBRAPA Tabuleiros Costeiros (Aracaju, SE, Brazil). The micropropagation was carried out using MS medium (Murashige and Skoog 1962) without growth phytoregulator as described by
Corrêa et al. (2009), Quoirin et al. (2008), Radmann et al. (2011) and Scherwinski-Pereira et al. (2009). The MS medium was supplied with 30 $\mathrm{g} / \mathrm{L}$ of sucrose and $7 \mathrm{~g} / \mathrm{L}$ of agar-agar. The $\mathrm{pH}$ was adjusted at 5.8 and the medium was autoclaved at $120^{\circ} \mathrm{C}$ for $15 \mathrm{~min}$. Inoculum was under s were done on aseptic conditions and light intensity of 52 $\mu$ moles $/ \mathrm{m}^{2}$.s at $27 \pm 2^{\circ} \mathrm{C}$ for $16 \mathrm{~h}$. The combination of growth regulators for adaptive phase were 2.5 $\mu \mathrm{mol}$ and $0.625 \mu \mathrm{mol}$ concentrations of amino benzyl purine (BAP) and acetil-naftalenic acid (ANA), respectively. These in the multiplication phase were 10 and $25 \mu \mathrm{mol}$ of concentrations of BAP and ANA, respectively. During the multiplication phase, the plants were grown for three and eight months (Corrêa et al. 2009; Quoirin et al. 2008; Radmann et al. 2011; Scherwinski-Pereira et al. 2009).

\section{Obtaining the Enzyme}

The raw extract was obtained from the leaf and stem of pineapples in vitro using $1 \mathrm{~g}$ mass which was macerated in $5 \mathrm{~mL}$ of $0.2 \mathrm{M}$ phosphate buffer at different $\mathrm{pH}$ (5.7, 6.7 and 7.7) and filtered twice in gauze (Almeida et al., 2002; Ferreira et al. 2011; Fileti et al. 2009 and 2010; Lopes 2005; Lopes et al. 2009 and 2012). Total protein was determined according to Bradford's method (Bradford 1976; Ferreira et al. 2007; Padilha et al. 2012; Severo Júnior et al. 2007) and enzymatic activity by the casein digestion method, or Kunitz's method, with modifications (Ferreira et al. 2011; Lopes 2005; Lopes et al. 2009; Silveira et al. 2009). The step to obtain the enzyme is shown in Figure 1.

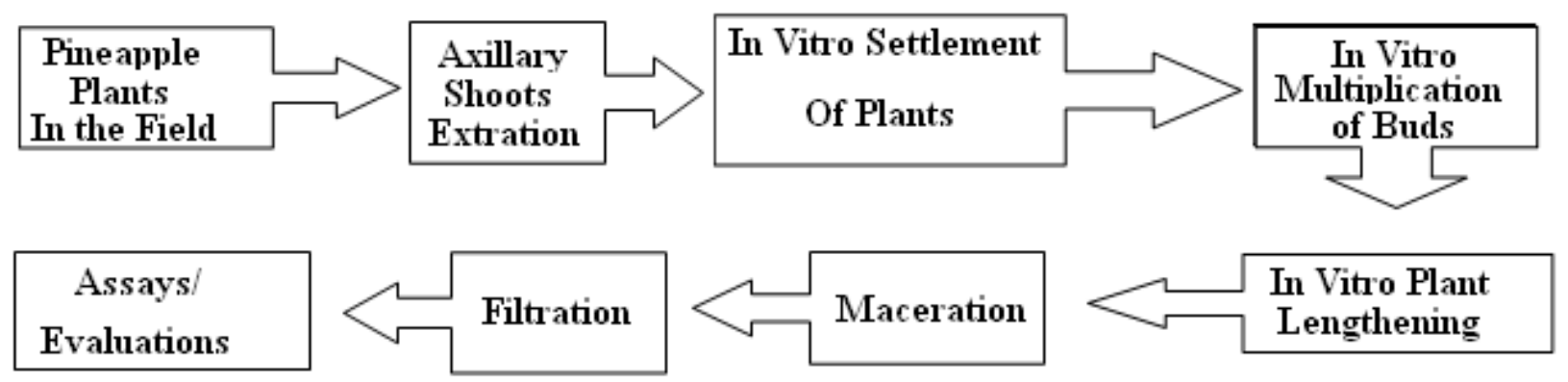

Figure 1 - Flowchart for in vitro production of plants and obtainment of bromelain enzyme raw extract.

\section{Preparation of Buffer Solutions}

Monobasic potassium phosphate $(24.36,12.72$ and $2.2 \mathrm{~g})$ and dibasic potassium phosphate $(1.18,6.2$ and $10.68 \mathrm{~g}$ ) were dissolved in $1000 \mathrm{~mL}$ of distilled water, respectively for $\mathrm{pH} 5.7,6.7$ and 7.7. Its $\mathrm{pH}$ was adjusted with phosphoric acid or potassium 
hydroxide (Morita and Assumpção 1995; Ferreira et al. 2011; Ferreira et al. 2007; Severo Júnior et al. 2007; Padilha et al. 2012; Severo Jr et al. 2009).

\section{Preparation of the Samples}

The leaves and stems from the in vitro Pérola and Imperial cultivars were macerated separately at different $\mathrm{pH}$ values (5.7, 6.7 and 7.7) of phosphate buffer filtered twice in gauze and evaluated (Kiss et al. 1995; Moreira et al. 1999 and 2006; Pasqual et al. 1998 and 2001).

\section{RESULTS AND DISCUSSIONS}

Table 1 presents the results of bromelain activities. In Pérola cultivar, the activity was lower when a buffer solution with higher $\mathrm{pH}$ was used and there was a reduction in the enzymatic activity when the plant cultivation time was longer. There was also a reduction in total protein as the cultivation time was longer, except at $\mathrm{pH} 7.7$

When comparing the cultivation time in a medium with no growth regulator, the concentration profiles were similar for both the ages and only differed in the basic region, where the leaf's extract whose cultivation time was longer showed an almost constant behavior as the three-month old leaves. $\mathrm{pH} 5.7$ showed the best results for all the cultivar parts and any cultivation period of time, demonstrating to be the optimal $\mathrm{pH}$ for this enzyme. Considering the best cultivations conditions for the Pérola cultivar, consisting of $\mathrm{pH}$ 5.7 and a 3-month cultivation for the leaves, enzymatic activity was $0.0194 \mathrm{U} / \mathrm{mL}$ and total protein had a concentration of $10.342 \mathrm{mg} / \mathrm{L}$.

Table 2 shows the results for Imperial cultivar. There was a reduction in bromelain enzyme activity when the $\mathrm{pH}$ in the extraction solution was increased; indicating that $\mathrm{pH} 5.7$ also should be optimal for this cultivar. However, enzymatic activity increased as the cultivation time increased either in the leaves or in plant stems, an inverse behavior of that presented by Pérola cultivar. Total protein showed a reduction when the cultivation time was longer, which was similar to Pérola's cultivar.

Table 1 - Bromelain's activity and protein concentration in the leaves and stems of Pérola cultivar regarding distinct cultivation times and $\mathrm{pH}$ values for buffer solution.

\begin{tabular}{ccccccccc}
\hline & \multicolumn{4}{c}{ Activity $(\mathbf{U} / \mathbf{m L})$} & \multicolumn{3}{c}{ Proteins (mg/L) } \\
pH & \multicolumn{2}{c}{ Leaves } & \multicolumn{2}{c}{ Stem } & \multicolumn{2}{c}{ Leaves } & \multicolumn{2}{c}{ Stem } \\
& 3 months & 8 months & 3 months & 8 months & 3 months & 8 months & 3 months & 8 months \\
\hline $\mathbf{5 . 7}$ & 0.0194 & 0.0050 & 0.0053 & 0.0097 & 10.342 & 10.679 & 6.3268 & 4.4458 \\
$\mathbf{6 . 7}$ & 0.0073 & 0.0008 & 0.0098 & 0.0040 & 12.796 & 11.652 & 7.5910 & 5.6837 \\
$\mathbf{7 . 7}$ & 0.0012 & 0.0002 & 0.0015 & 0.0010 & 1.5061 & 11.497 & 0.2559 & 5.4563 \\
\hline
\end{tabular}

Table 2 - Bromelain's enzymatic activity and protein concentration in leaves and stems of Imperial cultivar considering different cultivations times and phosphate buffer $\mathrm{pH}$ values.

\begin{tabular}{ccccccccc}
\hline & \multicolumn{4}{c}{ Activity $(\mathbf{U} / \mathbf{m L})$} & \multicolumn{3}{c}{ Proteins (mg/L) } \\
pH & \multicolumn{2}{c}{ Leaves } & \multicolumn{2}{c}{ Stem } & \multicolumn{2}{c}{ Leaves } & \multicolumn{2}{c}{ Stem } \\
& 3 months & 8 months & 3 months & 8 months & 3 months & 8 months & 3 months & 8 months \\
\hline $\mathbf{5 . 7}$ & 0.0107 & 0.0112 & 0.0148 & 0.0180 & 8.759 & 8.759 & 4.402 & 4.087 \\
$\mathbf{6 . 7}$ & 0.0083 & 0.0167 & 0.0000 & 0.0076 & 12.530 & 8.146 & 6.270 & 4.048 \\
$\mathbf{7 . 7}$ & 0.0030 & 0.0114 & 0.0067 & 0.0149 & 12.136 & 11.248 & 6.0381 & 3.995 \\
\hline
\end{tabular}

It was also noticed that the enzymatic activity was higher in the stems than in the leaves and total protein was higher in the latter. A good enzymatic activity for low protein concentrations is considered ideal as a high specific activity is obtained (activity/protein mass). So, the optimal condition to obtain bromelain enzyme from
Imperial cultivar in an in vitro production was the one in which the enzyme was extracted from the stem cultivated for eight months in a buffer phosphate at $\mathrm{pH} 5.7$, whose enzymatic activity was $0.0148 \mathrm{U} / \mathrm{mL}$ and total protein concentration was $4.087 \mathrm{mg} / \mathrm{L}$. 
Results of the Figure 2 corroborated with the analysis of Tables 1 and Table 2. It showed that high activities were found in the leaves for the Pérola pineapple variety and steam sample for the Imperial pineapple variety and both were high values for three months cultivation. When comparing the two varieties, the Imperial cultivar showed higher production potential for bromelain production than the Pérola cultivar.

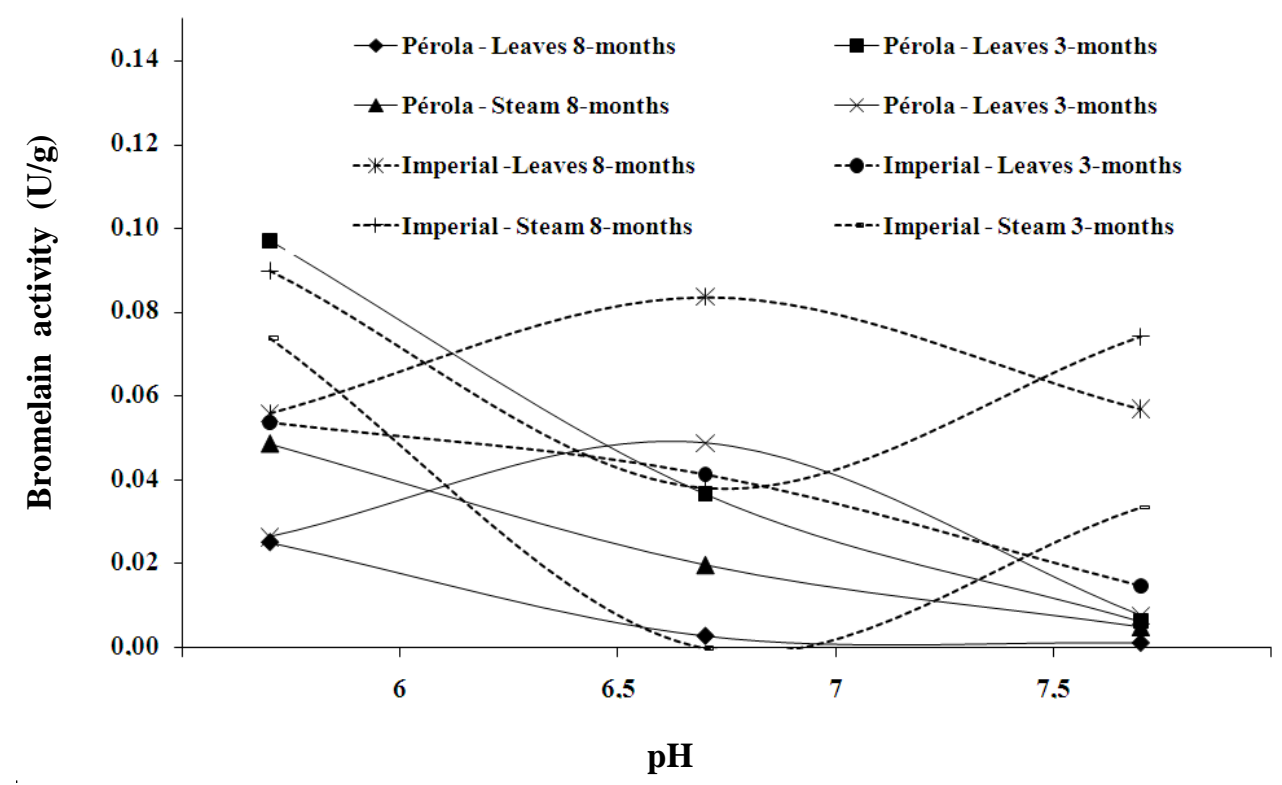

Figure 2 - Enzymatic activities for unity of pineapple plants.

Alcantara et al. (2011) and Pereira et al. (2011) found that longer period affected negatively the in vitro explant aspect, leading to a decrease in the survival of the plant during acclimatization for Eucalyptus grandis, Eucalyptus urophylla and apple plants. However, Radmann et al. (2011) observed that between 20-40 days of growth of 'Flordaguard' rootstock, longer cultivaion time was best. Scherwinski-Pereira et al. (2009) showed that effect of the growth time varied the seasons for the potato plants. The crop period was fast in springsummer (96 days) than autumm-winter (107 days). The micropropagation is used to maximize the plant growth. This technique decreases the production time and increases the productivity and resistance of plants to the diseases, helps in the regeneration, control in propagation genetic improvement, etc. There are other techniques such as genetic transformation that can be incorporated in a genetic breeding program in order to increase yields, shorten production cycles and promote the development of high quality plantations (Alcantara et al. 2011; Corrêa et al. 2009; Pereira et al. 2011;
Radmann et al. 2011; Scherwinski-Pereira et al. 2009).

\section{CONCLUSIONS}

Studies aimed to quantify bromelain obtained from the leaves and stems extracts of in vitro Perola and Imperial pineapple cultivars using a simple extraction with phosphate buffer at $\mathrm{pH}$ 5.7, 6.7 and 7.7, enabled the following conclusions:

- The proteolytic enzymatic activity in the pineapple plants in vitro extracts varied in function of extraction medium $\mathrm{pH}$, variety, part and age of the plant.

- The enzymatic activity increased as the $\mathrm{pH}$ of the phosphate buffer $\mathrm{pH}$ decreased.

- There was significant variation in protein concentration amount between the pineapple parts evaluated.

- For both the cultivars, the best $\mathrm{pH}$ for the extraction was 5.7. 
- The best cultivation time for Perola cultivar was the three month and for Imperial cultivar, it was eight months.

- The best part to obtain bromelain in Perola cultivar was its leaf, while in Imperial cultivar, it was its stem.

- Imperial cultivar had higher bromelain production potential than the Perola cultivar.

- The method used in this study was simple and economical, and efficient to evaluate the activity in the enzymatic preparations as well.

\section{ACKNOWLEDGEMENTS}

The authors thank the Brazilian Agricultural Research Corporation (EMBRAPA/Brazil), National Council for Scientific and Technological Development (CNPq/Brazil), Agency for the Improvement of Higher Education Studies (CAPES/Brazil) and Sergipe State Research and Technological Innovation Foundation (FAPITEC/SE, Brazil) for their financial support. The authors also acknowledge the valuable contributions of Dr. Sarah Brandão Santa Cruz Barbosa (in memoriam) during the execution of this study.

\section{REFERENCES}

Alcantara GB, Bespalhok Filho JC, Quoirin M. Organogenesis and transient genetic transformation of the hybrid Eucalyptus grandis $\times$ Eucalyptus urophylla. Sci Agri. 2011; 68(2): 246-251.

Almeida WAB, Santana GS, Rodriguez APM, Costa MAPdeC. Optimization of a protocol for the micropropagation of pineapple. Revista Brasileira de Frutic. 2002; 24(2): 296-300.

Barboza SBSC, Graciano-Ribeiro D, Teixeira JB, Portes TA, Souza LAC. Anatomia foliar de plantas micropropagadas de abacaxi. Pesq Agropec Bras. 2006; 41(2): 185-194.

Bradford MM. A rapid and sensitive method for the quantitative of $\mathrm{mg}$ quantities of protein, utilizing the principle of protein-dye binding. Anal Biochem. 1976; 72: 248-254.

Corrêa CM, Oliveira GN, Astarita LV, Santarém ER. Plant regeneration through somatic embryogenesis of yacón [smallanthus sonchifolius (poepp. and endl.) H. Robinson]. Braz Arch Biol Technol. 2009; 52(3): 549-554.

Ferreira GB, Evangelista AF, Severo Junior JB, Souza RRda, Santana JCC, Tambourgi EB, et al. Partitioning optimization of proteins from Zea mays malt in ATPS PEG $6000 / \mathrm{CaCl}_{2}$. Braz Arch Biol Technol. 2007; 50(3): 557-564.
Ferreira JF, Santana JCC, Tambourgi EB. The Effect of $\mathrm{pH}$ on Bromelain Partition from Ananas comosus by PEG4000/Phosphate ATPS. Braz Arch Biol Technol. 2011; 54(1): 125-132.

Fileti AMF, Fischer GA, Tambourgi EB. Neural Modeling of Bromelain Extraction by Reversed Micelles. Braz Arch Biol Technol. 2010; 53(2): 455463.

Fileti AMF, Fischer GA, Santana JCC, Tambourgi EB. Batch and Continuous Extraction of Bromelain Enzyme by Reversed Micelles. Braz Arch Biol Technol. 2009; 52(5): 1225-1234.

Hale LP, Greer PK, Trinh CT, James CL. Protein activity and stability of natural bromelain preparations. Int Immunopharmacol. 2005; 2: 783 793.

Kiss E, Kiss J, Gyulai G, Heszky LE. A novel method for rapid micropropagation of pineapple. Hort Sci., 1995; 30(1): 127-129.

Lopes FLG. Recuperação da bromelina a partir da polpa do Ananas comosus L. Merril, utilizando processos de separação por membrana [PhDl Thesis]. Campinas, Brazil: University of Campinas; 2005.

Lopes, FLG, Severo Júnior JB, Souza RRde, Ehrhardt DD, Santana JCC, Tambourgi EB. Concentration by membrane separation processes of a medicinal product obtained from pineapple pulp. Braz Arch Biol Technol. 2009; 52(2): 457-464.

Lopes FLG, Sbruzzi D, Barros KVG, Ferreira JF, Santana JCC, Souza RRde et al. Viability in the production of a drug extracted from Ananas comosus by a flat membrane system. Braz Arch Biol Technol. 2012; 55(3): 465-470.

Moreira MA, Pasqual M, Carvalho JG, Fráguas CB. Estiolamento na micropropagação do abacaxizeiro cv. Pérola. Ciênc Agrotec. 2003; 27(5): 1002-1006.

Moreira MA, Sobrinho AA, Pasqual M. Indução ao estiolamento in vitro de brotos de abacaxi cv. Pérola. Rev Univ Alfenas. 1999; 5: 193-197.

Morita T, Assumpção RMV. Manual de Soluções, Reagentes e Solventes. Padronização-PreparaçãoPurificação. $2^{\mathrm{a}}$ ed. São Paulo: Edgard Blücher Ltda; 1995.

Murashige T, Skoog F. A revised medium for rapid growth and bioassays with tabacco tissue cultures. Physiol plant. 1962; 15: 473-497.

Padilha GdaS, Santana JCC, Monte Alegre R, Tambourgi EB. Extraction of lípase from Burkholderia cepacia by PEG/phosphate ATPS and its biochemistry characterization. Braz Arch Biol Technol. 2012; 55(1): 7-19.

Park YK. Produção de enzimas Industriais de Origem vegetal. Biotecnologia Industrial. 1st ed. São Paulo: Edgard Blucher; 2001.

Pasqual M, Chalfun NNJ, Ramos JD. Aplicações na propagação de plantas. $1^{a}$ ed. Lavras: EDUFLA; 2001. 
Pasqual M, Moreira MA, Sobrinho AA. Biotecnologia aplicada à produção de mudas de abacaxi. Inf Agrop. 1998; 19(195): 20-23.

Pereira JES, Fortes GRL, Silva JB. Baixa temperatura para explantes do porta-enxerto de macieira 'marubakaido' in vitro durante a aclimatização. Sci Agric. 2011; 58(2): 401-405.

Quoirin MGG, Biasi LA, Rios JF, Cuquel FL. Micropropagation of Gypsophila paniculata through culture of nodal segments. Scientia Agraria, 2008; 9(4): 79-83.

Radmann EB, Bianchi VJ, Fachinello JC, Ferreira LV, Oliveira RP. In vitro multiplication of 'Flordaguard' rootstock: cytokinin source and concentration effects, explants orientation and period of permanence in the culture medium. Braz Arch Biol Technol. 2011; 54(1): 25-34.

Scherwinski-Pereira JE, Medeiros CAB, Fortes GRL, Pereira AS. Production of pre-basic potato seed by polyvinyl chloride PVC - articulate gutters hydroponic system. Braz Arch Biol Technol. 2009; 52(5): 1107-1114.
Severo Júnior JB, Oliveira LSS, Sardeiro FS, Souza RRde, Lopes FLG, Santana JCC, Tambourgi EB. Response surface methodology to evaluation the recovery of amylases by hollow fiber membrane. Braz Arch Biol Technol. 2007; 50(4): 713-718.

Severo Jr JB, Souza RRde, Santana JCC, Tambourgi EB. A study of ion-exchange chromatography in an expanded bed for bovine albumin recovery. Braz Arch Biol Technol. 2009; 52(2): 427-436.

Silveira E, Souza-Jr ME, Santana JCC, Chaves AC, Porto ALF, Tambourgi EB. Expanded bed adsorption of bromelain (e.c. 3.4.22.33) from Ananas comosus crude extract. Braz J Chem Eng. 2009; 26(1): 149157.

Received: March 16, 2011; Revised: June 21, 2011; Accepted: June 05, 2012. 